\title{
Justice, Work, and the Ghetto Poor
}

\section{Citation}

Shelby, Tommie. 2012. "Justice, Work, and the Ghetto Poor." The Law \& Ethics of Human Rights 6 (1): 71-96.

\section{Published Version}

doi:10.1515/1938-2545.1068

\section{Permanent link}

http://nrs.harvard.edu/urn-3:HUL.InstRepos:11899737

\section{Terms of Use}

This article was downloaded from Harvard University's DASH repository, and is made available under the terms and conditions applicable to Open Access Policy Articles, as set forth at http:// nrs.harvard.edu/urn-3:HUL.InstRepos:dash.current.terms-of-use\#OAP

\section{Share Your Story}

The Harvard community has made this article openly available.

Please share how this access benefits you. Submit a story.

Accessibility 


\title{
Justice, Work, and the Ghetto Poor
}

\author{
Tommie Shelby \\ Harvard University \\ tshelby@fas.harvard.edu
}

In the United States, a ghetto is a predominantly black, metropolitan neighborhood with a high concentration of poverty ( 40 percent or more below the federal poverty line). ${ }^{1}$ Joblessness is an influential and compelling explanation for why ghettos persist in the post-civil rights era. According to this view, it is the fact that so many among the ghetto poor do not work regularly that best explains why those in these communities often remain poor. Some advocates of this view maintain moreover that, not only does concentrated joblessness keep the ghetto poor in poverty, but joblessness has negative ramifications far beyond mere income disadvantage. For instance, joblessness is said to increase crime and juvenile delinquency, to encourage welfare dependency and single-parent households, to undermine personal dignity and self-respect, to foster a pathological ghetto subculture, and to weaken crucial institutions of civil society (e.g., churches, political organizations, neighborhood social networks, and other voluntary associations).

In view of the significance of joblessness, some social scientists, policymakers, and commentators have advocated strong measures to ensure that the ghetto poor work, including mandating work as a condition of receiving welfare benefits. Indeed, among both conservatives and liberals, work is often seen as a

\footnotetext{
1 See Paul A. Jargowsky, Poverty and Place: Ghettos, Barrios, and the American City (New York: Russell Sage Foundation, 1997), pp. 12-17.
} 
moral or civic duty and as a necessary basis for personal dignity. And this normative stance is now instantiated in federal and state law, from the tax scheme to welfare benefits to employment regulation. ${ }^{2}$

My aim is to reflect critically on this new regime of work. I ask whether the normative principles to which its advocates typically (though sometimes tacitly) appeal actually justify the regime. In attempting to answer this question, I scrutinize the idea that there is a general duty to work, specify what type of duty it might reasonably be thought to be, and identify the kinds of activities that could plausibly count toward fulfilling it. I conclude that the case for a pro tanto moral or civic duty to work is not as strong as many believe and that there are reasonable responses to joblessness that do not involve instituting a work regime. But even if we grant that there is a duty to work, I maintain that the ghetto poor would not be wronging their fellow citizens were they to choose not to work and to rely on public funds for material support. In fact, I will argue that many among the black urban poor have good reasons to refuse to work. Throughout, I will emphasize what too few advocates of the new work regime do, namely, that whether work is an obligation depends crucially on whether background social conditions within the polity are just. $^{3}$

\footnotetext{
2 See Ron Haskins, Work Over Welfare: The Inside Story of the 1996 Welfare Reform Law (Washington, DC: Brookings Institution Press, 2006); and Marisa Chappell, The War on Welfare: Family, Poverty, and Politics in Modern America (Philadelphia: University of Pennsylvania Press, 2010).

3 I will focus my discussion on the black urban poor, for I believe that they, as a social group, occupy a unique social position in the U.S. social order and that they have the strongest reasons to refuse to cooperate with the new work regime. However, many of the arguments I will put forward apply to other social groups burdened by injustices imposed by the U.S. basic structure (e.g., Native Americans, some Hispanic groups, and the rural white poor).
} 


\section{SOCIAL JUSTICE AND THE NEW WORK REGIME}

Who are the "jobless"? The category jobless is not coextensive with the category unemployed, at least not as the latter is traditionally understood. The jobless include both those able-bodied adults who are unemployed but looking for work and those able-bodied adults who are unemployed but who, for reasons other than retirement, have dropped out of the workforce.

Why are the jobless not working? Some common explanations emphasize involuntary joblessness. For instance, some among the ghetto poor may not work because jobs are simply unavailable, that is, the labor market is slack and the ghetto poor represent surplus labor. Because of economic restructuring and globalization, there is also a mismatch between skills and jobs: most (decent) jobs that are available in the United States are largely for highly skilled or educated workers and the ghetto poor often lack the skills and education needed for success in the new economy. Where there are jobs for low-skilled workers, there is sometimes a mismatch between the location of these jobs (suburbs) and the residences of the black poor (inner city), and this special mismatch is exacerbated by an inefficient and underdeveloped mass transit system and by housing discrimination and high rents in suburban neighborhoods, which effectively keep the ghetto poor from residing in communities where good jobs are more plentiful. There is also continuing employment discrimination in the low-wage labor market, particularly on grounds of race and gender. Sometimes poor single mothers are unable to find adequate or affordable childcare, which forces these women to stay at home to care for their children. Then there are those ghetto denizens who are addicted to drugs, 
suffer from mental illness or other disabilities, or have criminal records, characteristics that make it difficult for them to acquire or hold down a steady job, at least without substantial support. These explanations are not mutually exclusive. What they all have in common is that they highlight factors outside the control of the ghetto poor. ${ }^{4}$

However, when it comes to explaining why the ghetto poor are not working, some emphasize voluntary joblessness. In other words, some ghetto denizens choose not to work even though there are jobs they could get if they sought them. It is this case of voluntary non-work that angers many U.S. citizens and that advocates of the work regime hope to remedy.

Now some claim that the ghetto poor have chosen not to work because it is not in their material interests to do so. On this view, a rational cost-benefit analysis demonstrates that, say, unconditional welfare or the illegal drug trade would be a better option, all things considered. Thus, some advocates of the new work regime have responded by (1) ending welfare as an entitlement, replacing it with strict time limits and work requirements for benefit eligibility, and (2) cracking down on urban crime, and especially on the drug trade, pushing for long prison terms and other aggressive punitive measures. The idea here is to change the incentive structure to encourage work.

Others go further, claiming that the ghetto poor choose not to work, not simply out of economic interests, but because of character flaws or other moral

\footnotetext{
4 William Julius Wilson has defended an account that systematizes these various factors into a compelling explanation of ghetto poverty. See his When Work Disappears: The World of the New Urban Poor (New York: Knopf, 1996).
} 
failings. These advocates of the work regime believe that the ghetto poor's voluntary non-work is morally blameworthy and irresponsible. Their recommended policy response is to craft laws and to design institutions such that the ghetto poor are effectively compelled to work, or punished if they continue to refuse.

Implicit in this policy response is the assumption that the reasons the black urban poor have for refusing to work are not, or could not be, sufficient to justify this refusal. This assumption is widely held, quite old, and sometimes accepted by respected black leaders. For instance, at the turn of the twentieth century, Booker T. Washington and W. E. B. Du Bois, despite their other well-known political differences, agreed that many blacks remained economically disadvantaged because they willfully avoided gainful employment. This tendency to avoid work, which they attributed to socialization under slavery, makes black families economically vulnerable and dependent and slows the advancement of the race as a whole. Neither black leader asked whether (some) blacks might be justified in refusing to accept the jobs that were available to them.

I agree that high jobless rates in ghettos are worrisome and have farreaching consequences. However, it does not follow from this social analysis that inducing or mandating work is the right solution to the problem of ghetto poverty. The new work regime is premised on the assumption that there is a duty to work (at least as an obligation of the poor) and that it is morally permissible for the state to mandate work (or at least that the poor may be compelled to work). Neither assumption is obvious. And a variety of alternative responses to voluntary nonwork on the part of the ghetto poor are possible and plausible, or so I will argue. 
We must keep in mind that every policy solution to ghetto poverty is premised, if only implicitly, on a set of moral and political values. Technocratic approaches to social problems tend to obscure this point or to avoid questions of basic justice altogether. For this reason, questions of basic justice are best taken up from the standpoint of the citizen. Citizens are subject to the powerful, life-shaping influences of government, commerce, and bureaucratic modes of social organization and they therefore have a profound stake in the overall justice of the institutional arrangement that so affects their lives. If basic social justice is viewed from this perspective, the problem can be seen in a different light. Rather than opt for social engineering projects that aim merely to reduce or limit poverty, we may seriously consider broad social justice initiatives whose fundamental objective is to bring the basic structure of society in line with egalitarian principles of social justice.

Against the background of these remarks, let me suggest another factor-a moral factor-in the explanation for why some among the ghetto poor choose not to work. Perhaps some do not accept the jobs available because they believe the basic structure of U.S. society is deeply unfair and thus on grounds of justice and self-respect refuse to accommodate themselves to their low position in this stratified social order. ${ }^{5}$ Refusing to work can be a manifestation of dissatisfaction with the current social arrangement, the expression of an unwillingness to cooperate with an unjust system. Though the oppressed may be keenly aware of their impoverished

\footnotetext{
5 This position is different from the one defended by Howard McGary, who argues that because the ghetto poor regard the basic structure of U.S. society as unjust, many, sensing the deck is stacked against them, lack the motivation to overcome all the obstacles they face in order to succeed. In particular, they are not motivated to work hard or perhaps to work at all. (See Howard McGary, "The Black Underclass and the Question of Values," in Bill E. Lawson, ed., The Underclass Question [Philadelphia: Temple University Press, 1992], pp. 57-70.) I agree that some may not be motivated to work because of the unfairness of the social scheme. But I want to go further to claim that some may consciously refuse to work because of this unfairness.
} 
circumstances, rather than comply with what they take to be unreasonable societal expectations, they sometimes decline to acquiesce to the status quo even when their material prospects might be made worse as a result. Based on compelling interpretations of the vernacular and expressive culture that emanates from and appeals to many in the ghetto, I am confident that some among the ghetto poor take exactly this stance of passive resistance, or something similar. ${ }^{6}$ I concede that I do not know how large this group is; nor can I prove that their number is significant. It may be a small minority. However, regardless of its size, there is, I believe, progressive political potential in the stated moral stance. My goal is not to show that this stance is widespread but that it is justified.

Social scientists and commentators who write about ghetto poverty rarely take the moral reasons of the black urban poor seriously, particularly when these reasons sharply diverge from mainstream opinion. ${ }^{7}$ Some do acknowledge that the poor's refusal to work can sometimes represent a "protest" against low-paying and demeaning jobs. ${ }^{8}$ But they rarely suggest that, rather than being against a particular job opportunity, this protest is against an institutional framework that affords them only such poor employment options. ${ }^{9}$ Others accept that some in the ghetto choose non-work as a form of protest against "the system," but they think these claims of

\footnotetext{
${ }^{6}$ See Robin D. G. Kelley, Yo Mama's Disfunktional!: Fighting the Culture Wars in Urban America (Boston: Beacon Press, 1997).

${ }^{7}$ For important exceptions to this, see Elijah Anderson, Code of the Street: Decency, Violence, and the Moral Life of the Inner City (New York: Norton, 1999); Alford A. Young, Jr., The Minds of Marginalized Black Men: Making Sense of Mobility, Opportunity, and Future Life Chances (Princeton: Princeton University Press, 2004); Kathryn Edin and Maria Kefalas, Promises I Can Keep: Why Poor Women Put Motherhood Before Marriage (Berkeley: University of California Press, 2005); and Sandra Susan Smith, Lone Pursuit: Distrust and Defensive Individualism Among the Black Poor (New York: Russell Sage Foundation, 2007);

8 See, e.g., Stephen M. Petterson, “Are Young Black Men Really Less Willing to Work?” American Sociological Review 62 (1997): 605-613.

${ }^{9}$ For an exception, see Lawrence M. Mead, Beyond Entitlement: The Social Obligations of Citizenship (New York: Free Press, 1986), pp. 78-79.
} 
injustice have little or no merit and now serve only to rationalize (or to provide psychological compensation for) non-workers' individual failures. ${ }^{10}$ Mostly, commentators simply assume that the U.S. liberal-capitalist order is basically just and that labor-market outcomes are fair provided employers do not discriminate.

\section{WHAT IS “WORK”?}

In debates about work and welfare, there is much ambiguity about the meaning of "work." Articulating and defending a general account of what constitutes work would take us too far afield. But, as we assess the new work regime, it will help to see that what should count as "work" depends on the point of demanding work from the ghetto poor. If, for example, the point is to ensure that the ghetto poor are not a financial burden ("parasites" or "freeloaders") on their fellow citizens, then "work" might be defined as any activity that the market remunerates, including work in the underground economy. If the point is to bring discipline and order to the lives of the ghetto poor (a type of character rehabilitation), then "work" might include almost any structured and supervised activity, regardless of whether it is paid, including volunteer work or community service. If the point is to discourage the supposed vice of "welfare dependency" and to foster economic self-reliance, then any compensated activity, whether paid by the market or by government funds, could count as "work."

Many complain that the non-working poor are failing to make a useful contribution to society while simultaneously benefitting from the productive

10 John McWhorter, Winning the Race: Beyond the Crisis in Black America (New York: Gotham Books, 2005), chap. 5. 
contributions of others. But often those with this complaint regard "work" as any (legal) activity for which a person gets paid. This however misleadingly conflates earning income through market-remunerated activity with making a positive contribution to society. It would leave out lots of socially beneficial activities for which people are often not paid. Feminists have argued persuasively that care work-i.e., care for children, the sick, the disabled, and the elderly-is typically performed by women, generally devalued by society, and mostly unpaid. ${ }^{11}$ Given how socially important, even necessary, such work is, this is profoundly unfair, especially if these women are also expected to do paid work and men are expected to do little if any care work. If the point of demanding work is that the ghetto poor should engage in activities that contribute to the public good, then it is hard to see why care work should not count.

In addition, due to environmental dangers, technological advances, and cheap low-skilled labor in other parts of the world, it may be more efficient, costeffective, or otherwise beneficial to discourage some people from participating in the U.S. labor market, at least as it is currently structured. They could still do socially useful work that the market will not reward, e.g., building infrastructure, protecting the environment, or maintaining public parks.

Insofar as work should involve making a positive contribution to society, one might also object to regarding as "work" certain paid activities that, though lawful, have a negative impact on society, e.g., the production and sale of pornography or

\footnotetext{
11 See, for example, Eva Feder Kittay, Love's Labor: Essays on Women, Equality and Dependency (New York: Routledge, 1999); and Virginia Held, The Ethics of Care: Personal, Political, and Global (New York: Oxford University Press, 2006).
} 
the running of legal gambling establishments. The fact that there is a market for such goods and services does not mean that, overall, they contribute to social welfare.

Another ambiguity in debates over work and welfare concerns time. Any duty to work must include some, at least implicit, time dimension. Advocates of the new work regime often seem to assume that "workers" should always be working, that is, occupying a full-time job (forty or more hours a week), at least fifty weeks a year (excluding leaves for illness, injury, or maternity), every year of their adult lives (excluding periods of full-time education), until retirement age. But why are these the only kind of "workers" who have fulfilled their moral or civic duties with respect to work? Arguably, we should consider someone a worker in good moral or civic standing even if he or she takes periods off from work-e.g., to do care work (if this is not considered "work"), to augment or develop new skills, to participate in activities that, though not considered "work," promote social welfare, or to just take a break to do something more intrinsically or personally satisfying. And even during the periods when one is working, how much work is adequate-eight, six, or four hours a day; forty, thirty, or twenty hours a week; fifty, forty-five, or forty weeks a year? Indeed, in a society that places a high value on individual liberty and choice, one could imagine a prevailing work regime in which each able-bodied citizen is expected to work a certain number of hours (days, weeks, or years) over a lifetime, where each has the right to decide how these hours (days, weeks, or years) are to be distributed over the course of his or her life, provided the sum reaches the 
designated number. Setting aside the details, the point is, even in a society that regards work as a duty, there are a variety of work regimes possible.

\section{FULL CITIZENSHIP WITHOUT A DUTY TO WORK}

Could a democratic society be just in the absence of a general duty to work? Before considering defenses of a moral or civic duty to work, let me briefly mention three alternative social arrangements that do not require work as a condition of full civic standing.

Some political theorists, in particular those committed to libertarianism, emphasize, not work per se, but economic self-reliance or independence. They hold that individuals or family units have an obligation to be economically self-sufficient. No one should rely on their fellow citizens for assistance, unless perhaps they are physically or psychologically incapable of supporting themselves. On this view, each citizen has a duty to make material provision for himself or herself and for his or her dependents (e.g., children or elderly parents). Citizens should not (willingly) burden one another by calling on the resources or labor of other citizens as a means of support. Most important, no citizen has a civic duty, enforceable by the state, to meet the material needs of others-though a citizen may have an unenforceable moral duty to give to the needy. There is no general civic requirement that all work, however, since citizens may support themselves through investments if they are wealthy or through the goodwill of family, friends, or charities if they are poor. The key point is that citizens, regardless of whether they have adequate resources, have no valid justice-based claim against their government or fellow citizens for support. 
Though a general work regime, applicable to all citizens, cannot be justified on libertarian principles, a society that made welfare benefits conditional on work might be defensible. It could be argued that though there is no general civic obligation to work or to cultivate a strong work ethic, if welfare benefits are provided, those able-bodied persons who expect these benefits should have to work as a condition of receiving them. Since self-supporting citizens have no civic duty to support the poor, it is perfectly just for would-be benefactors to demand work from their beneficiaries. A possible other-regarding rationale for this demand is that unconditional welfare benefits encourage dependency, whereas welfare benefits conditional on work encourage self-sufficiency. Through such work, welfare beneficiaries would learn to become self-supporting and will be better off for it. A more self-interested rationale is that self-supporting citizens should get something in return for supporting citizens who are not economically self-sufficient. There is, as it were, no free lunch, so the poor should perform socially useful work in exchange for the material provisions they receive.

Though I will not argue against it here, I do not believe that the libertarian conception of justice is correct. ${ }^{12}$ But even were we to adopt libertarian principles, the case for the fairness of welfare benefits conditional on work, at least as it applies to the ghetto poor, would be weak. In addition to advocating limited government and free markets, libertarian accounts of justice all emphasize justice in economic appropriation and transfer, including intergenerational wealth transfers through

\footnotetext{
12 Forceful criticisms of libertarianism can be found in G. A. Cohen, Self-Ownership, Freedom, and Equality (Oxford: Oxford University Press, 1995); Samuel Freeman, "Illiberal Libertarians: Why Libertarianism Is Not a Liberal View," Philosophy \& Public Affairs 30 (2001): 105-151; and Liam Murphy and Thomas Nagel, The Myth of Ownership: Taxes and Justice (Oxford: Oxford University Press, 2002).
} 
inheritance, as fundamental to a legitimate polity. ${ }^{13}$ They also emphasize the importance of having a dynamic conception of societal justice, where material progress over time is regarded as the appropriate standpoint for judging the justice of social arrangements, rather than taking a static or end-result view of citizens' holdings and material welfare, which might seem to justify redistributive measures. ${ }^{14}$

Yet given the history of slavery and Jim Crow-three and a half centuries of gross and far-reaching injustices on almost anyone's principles-no one can plausibly argue that the current, racially skewed distribution of resources is a result of just appropriations and transfers. ${ }^{15}$ Nothing approaching reparations for slavery or Jim Crow has been offered to the descendants of slaves or the victims of the segregation regime. Given that contemporary ghetto poverty can be explained, at least in part, by historical injustices in appropriation and transfer, it is far from clear that welfare conditional on work, which assumes just background conditions, is justifiable to the black urban poor. If blacks were not burdened by the injustices of the past or had been compensated for the disadvantages they have inherited, ghettos probably would not exist and there would likely be few blacks that were not self-supporting.

An alternative conception of full citizenship that also does not regard work as a civic requirement holds that citizens are entitled to a guaranteed, unconditional

\footnotetext{
13 See, for example, Robert Nozick, Anarchy, State, and Utopia (New York: Basic Books, 1974), pp. 150-153.

14 Nozick, Anarchy, State, and Utopia, pp. 153-167.

15 See Melvin L. Oliver and Thomas M. Shapiro, Black Wealth/White Wealth: A New Perspective on Racial Inequality (New York: Routledge, 1995); Dalton Conley, Being Black, Living in the Red: Race, Wealth, and Social Policy in America (Berkeley, CA: University of California Press, 1999); and David Lyons, "Corrective Justice, Equal Opportunity, and the Legacy of Slavery and Jim Crow,” Boston University Law Review 84 (2004): 1375-1404.
} 
basic income or initial capital stake. ${ }^{16}$ On this view, each individual has a right to his or her fair share of society's assets, which have been built up over many generations; and each should be free to use this fair share as he or she sees fit. Those who want to work, either for greater income or intrinsic satisfaction, are free and perhaps encouraged to do so. But those who do not work and live, at least for a time, off their basic income or capital stake are not acting unfairly toward their fellow citizens. The goods and services that we all take advantage of are the product of, not only contributions from contemporary workers, but work from past generations and, just as important, technological advance and nature's bounty. One's fellow citizens have no right to complain if one takes one's per capita share of these assets without agreeing to work. On this view, there should be an all-volunteer workforce, where no one is compelled to work under threat of penalty or out of economic need. Compulsory service would be required only under special circumstances (e.g., shortages in basic material necessities). Fiscal policy would focus on growing the economy (GDP) and spurring technological advance, while tax policy would distribute the gains of increased productivity equitably to all citizens and not just to those who work or own capital.

A similar but less radical view holds that citizens have an unconditional right to basic welfare benefits if they are in need. ${ }^{17}$ Those who have adequate means of support, either through voluntary work or personal wealth, are not entitled to the benefit. The welfare entitlement could perhaps be means-tested but need not

\footnotetext{
16 See Philippe Van Parijs, Real Freedom for All: What (if Anything) Can Justify Capitalism (Oxford: Oxford University Press, 1995); and Bruce Ackerman and Anne Alston, The Stakeholder Society (New Haven: Yale University Press, 1999).

17 Trudy Govier, "The Right to Eat and the Duty to Work," Philosophy of the Social Sciences 5 (1975): 125-143.
} 
depend on demonstrating a willingness to work. The idea would be that welfare benefits should be extended, as a social right, to those unable to find work, those incapable of working, and those who do not want to work. Both this regime and the one described in the previous paragraph assume an economy in which enough people will freely choose to work, either for intrinsic satisfaction or monetary gain, such that all citizens could live a decent life without there being any general societal demand that all able-bodied citizens work. It is of course an empirical question whether such a regime could be realized or would be stable over time. ${ }^{18}$

\section{WORK AND HUMAN FLOURISHING}

Americans are known for their work ethic. On one interpretation of this ethic, work—and perhaps hard work (whether measured in time, sacrifice, or exertion)— is a central element of a broad conception of human flourishing, or what Rawls would call a "comprehensive conception of the good."19 Political liberalism (as opposed to comprehensive liberalism) denies that a liberal-democratic state can legitimately enforce any particular conception of the good (sometimes called "the principle of liberal neutrality"). On this view, the state should be tolerant of different

\footnotetext{
18 It is worth noting that even if there is no civic obligation to work, a person would have a natural duty to work if, under the circumstances, only work would ensure adequate material provision for his or her children. Civic duties are the obligations that exist between citizens of a democratic polity and that have binding normative force because of the contingent associational ties between citizens. Natural duties are unconditionally binding; that is, they hold between all persons regardless of whether they are fellow citizens. A person would have natural duties even in the state of nature or under an unjust regime. So, even if the ghetto poor are unfairly limited to jobs that are menial, low-paying, and insecure, they would not be morally justified in refusing them if such employment were the only way they could acquire the income needed to support their children. It may be possible to mount a successful argument that shows that even in an unjust society, the state (or private actors using the formal machinery of the state) could legitimately force parents to fulfill this natural duty. However, I will not pursue this possibility here.

${ }^{19}$ Living in accordance with the work ethic involves more than choosing work over idleness. For instance, one is to work diligently, conscientiously, and responsibly; one is to be on time for work, never to complain about the demands of work, and to put in extra time and effort if doing the job well requires it. I will leave aside these other dimensions of the work ethic, for my argument does not turn on them.
} 
conceptions of the good, provided these are compatible with the maintenance of a just social structure, rather than attempt to mold individuals in accordance with some contested conception of human flourishing. Individuals should be free to develop and live according to their own comprehensive moral conception, which may include a contested view about which kinds of activities or lives are meaningful and worthwhile, so long as they live up to their civic obligations.

There are, however, people who believe that the state not only may encourage a conception of the good that includes an ethic of work but may legitimately enforce it. These political perfectionists are similar to (and sometimes include) those who believe that a Christian life is the only worthwhile life and that government may use its power to promote Christianity and to discourage nonChristian forms of life. Like some Christians, these advocates of the new work regime view laziness as a serious moral vice or character flaw and thus think voluntary non-workers warrant the contempt of their fellow citizens. Many hold that being a working person is necessary for having a positive sense of self-worth or dignity and thus that the idle have reason to feel shame or guilt. ${ }^{20}$

Of course, social conservatives are not the only ones who view work as necessary for human flourishing. Karl Marx, a perfectionist of a rather different sort, also believed that work is a key component of human self-realization. On his conception of the good, freely engaging in socially useful and intrinsically meaningful work is the essence of human fulfillment. Unlike social conservatives,

\footnotetext{
${ }^{20}$ For a discussion of the historical origins of this ideology, see Judith Shklar, American Citizenship: The Quest for Inclusion (Cambridge, Mass.: Harvard University Press, 1991). The racial, gender, and class dimensions of this worldview are examined in Michelle Lamont, The Dignity of Working Men: Morality and the Boundaries of Race, Class, and Immigration (New York: Russell Sage, 2000).
} 
however, Marx did not think wage-labor qualified as the relevant kind of work. He had several reasons for thinking this; here I mention two. First, people who perform wage-labor typically do so, not because it contributes to fulfilling the needs of others or because they find it intrinsically satisfying, but only because it satisfies their own narrow, material needs-i.e. because it pays the bills. Second, and more important for present purposes, Marx did not think work could be truly fulfilling unless it was freely chosen. In other words, truly fulfilling work cannot be compelled, either by the state or by market imperatives.

The contrast between these two conceptions of work as a source of the human good is instructive. The particular lesson I want to highlight is the tension between valuing work as a component of human flourishing and advocating a political regime that forces people to work. If it is to be a valid source of self-esteem or an expression of virtue, work must be engaged in for the right reasons. If a person works only because he or she would otherwise live in a perpetual state of material deprivation or because he or she seeks to avoid the disdain of fellow citizens, it is hard to see the moral worth of such work. Pride and self-approbation do not seem to be the appropriate response. Shouldn't one work because this is what being a good person (or good citizen) demands and not simply because the state will come down on you if you refuse? The question I am asking is not so much whether it would be legitimate to enforce a work ethic but whether such an ethic could be enforced and 
still play the role in human fulfillment that those who value it have in mind. I doubt it. $^{21}$

Advocates of the American work ethic might concede that forced work cannot function as a valid source of pride or an expression of virtue. They may nonetheless insist that the state should strongly discourage and perhaps punish idleness. It should do so either because such sanctions may, in time, effect a positive change in the moral motivation of the lazy (and thus serve an educative function) or because such sanctions will help to preserve a general societal ethos of work (presumably necessary to sustain a prosperous nation and virtuous citizenry) even if they do not change (all) those to whom the sanctions are applied. These variants are worthy of further consideration. My primary interest, however, is in those defenses of the new work regime that might be compatible with political liberalism, and work-ethic justifications do not qualify, despite their obvious appeal to many in the United States.

\section{WORK AND RECIPROCITY}

Probably the most influential and compelling defense of a civic duty to work that does not rely on a controversial conception of human flourishing is based on the idea of reciprocity. There are, however, different ways of understanding "reciprocity" and thus different ways of justifying a civic duty to work. Let me distinguish three approaches.

\footnotetext{
21 In registering this doubt, I do not mean to deny that a person forced to work might nevertheless find some satisfaction or meaning in the work he or she is compelled to do. Rather, insofar as human flourishing requires working for the right reasons (e.g., because virtue or our "species being" requires it) and not simply due to duress, a work regime founded on this conception of the good would be self-defeating.
} 
One approach uses a benefactor/debtor model. On this model, "society," understood as a collective agent or perhaps quasi-parent, is said to provide each citizen with many indispensible goods and services. Therefore each citizen owes a debt to society, which is to be paid, at least in part, through socially useful work. This reciprocity argument suggests that the non-contributing person's moral fault is being ungrateful. A simple "thanks" is not sufficient; each must show his or her appreciation by contributing socially beneficial labor. On this model, the benefits that each citizen receives by living in society come from the generosity or goodwill of his or her government (or fellow citizens); these benefits are not something that each citizen is owed simply in virtue of his or her membership in the polity.

A different approach to thinking about reciprocity is to model it on market exchanges for mutual advantage. One version of this view asserts that government provides many benefits to citizens—physical security, social services, a regulated market, the rule of law, and so on. In exchange for these benefits, the state reasonably expects, not only obedience to law, but also socially beneficial work. This puts individual citizens in a semi-contractual relation with their government. The benefits of governance are not provided unconditionally (as an entitlement or right) but are offered in exchange for work. In a sense, the benefits are merely advanced, like a loan, with the expectation that they will be paid back, not in kind, but with socially useful work. The citizen who receives the benefits of governance but fails to perform work in exchange has therefore defaulted on a loan or violated a contract. Voluntary non-work is, in effect, a breach of the civic contract. 
Perhaps the most persuasive version of the reciprocity argument appeals to considerations of fairness. ${ }^{22}$ On this view, each citizen should make some labor contribution to the public good in light of the benefits of social cooperation he or she enjoys. Those who cooperate make sacrifices and take risks to produce the goods and services from which all in society benefit. It would be wrong, a form of parasitism or free-riding, to take advantage of the cooperative labor of others without making a labor contribution of one's own. The non-contributor's moral error is that he or she acts unfairly in refusing to work. ${ }^{23}$

All three versions of the reciprocity argument have some plausibility and thus are worthy of consideration. But before examining the implications of this argument for voluntary non-work among the ghetto poor, there are several preliminary questions we should ask. First, the basic form of the argument is to claim that all citizens benefit from what government or others in society have done and thereby owe something in return. Even if it is conceded that, because of benefits received, something is owed, why is work the only way to pay the debt? One might argue that conforming to the dictates of law and respecting private property, both of which entail restricting one's liberty to do as one pleases, is payment enough. The loss of liberty and burden of self-restraint are real costs, after all; and each member of society benefits from the fact that others comply with the law and honor property claims. Supporting the government and complying with the demands of a market-

\footnotetext{
22 Though Rawls does not defend a civic obligation to work, the relevant conception of reciprocity is developed in John Rawls, Political Liberalism (New York: Columbia University Press, 1996), pp. 15-18.

23 This form of argument is advanced by, for example, Lawrence C. Becker, “The Obligation to Work," Ethics 91 (1980): 35-49; Mead, Beyond Entitlement; Amy Gutmann and Dennis Thompson, Democracy and Disagreement (Cambridge, Mass.: Harvard University Press, 1996), chap. 7; Mickey Kaus, The End of Equality (New York: New Republic/Basic Books, 1996); and Stuart White, The Civic Minimum: On the Rights and Obligations of Economic Citizenship (Oxford: Oxford University Press, 2003).
} 
based society could be an expression of gratitude for the benefits of social life, something of value offered in exchange for material support or a contribution to the maintenance of a polity defined by the rule of law. ${ }^{24}$

Second, why should we think that a duty to work exists even in those societies in which a labor contribution from everyone is not needed to supply essential goods and services? The reciprocity argument is most powerful when the benefits provided are not just valued by the beneficiary but, in some sense, needed by the beneficiary. ${ }^{25}$ There is, to use old-school Marxist terminology, socially necessary labor, and then there is surplus labor. It may be that in the United States today, socially necessary labor does not require all able-bodied individuals to work and a voluntary work regime would be sufficient to supply all the goods and services that are needed for all to live a decent, even comfortable, life. This situation is already true of military service: citizens of the United States are afforded adequate security from external threats without mandating that all able-bodied citizens serve in the military. An all-volunteer military is sufficient. Why restrict the liberty of, or impose costs on, citizens when this is not necessary?

Third, even if there is a reciprocity-based civic obligation to work, it is not clear that the state has the authority to enforce it. ${ }^{26}$ Should the failure to fulfill the duty to work result in downgraded civic standing, such that material support may

\footnotetext{
${ }^{24}$ Some argue that universal basic income and unconditional welfare benefits are compatible with the principle of reciprocity. See Catriona McKinnon, "Basic Income, Self-Respect, and Reciprocity," Journal of Applied Philosophy 20 (2003): 143-158; and Shlomi Segall, "Unconditional Welfare Benefits and the Principle of Reciprocity," Politics, Philosophy, \& Economics 4 (2005): 331-354

25 Klosko's account, with its emphasis on "presumptive benefits," takes this form. See George Klosko, The Principle of Fairness and Political Obligation (Lanham, MD: Rowman \& Littlefield, 1992), chap. 2.

${ }^{26}$ Segall rightly points out that even if a civic obligation to work is enforceable, it does not follow that the penalty for non-work should be the withholding of welfare benefits or basic income. See Segall, "Unconditional Welfare Benefits and the Principle of Reciprocity," p. 340.
} 
permissively be withheld or withdrawn? Perhaps the voluntary non-worker, like the person who chooses not to vote, should be regarded as a bad citizen or as unpatriotic. Perhaps he or she should not garner the esteem or respect of their fellow citizens, and may even merit their contempt. But just as many consider it wrong to enforce a civic duty to vote, we might also consider it wrong to enforce a civic duty to work. Moreover, as others have noted, it may be difficult to define "socially useful work" in the precise way needed for a law to be impartially administered and consistent with liberal neutrality. ${ }^{27}$ And gathering the information about who is shirking or incapable of contributing may be demeaning, intrusive, and insulting. ${ }^{28}$ Furthermore, on the benefactor/debtor conception of civic duties, it would be morally perverse, and perhaps self-defeating, to force the ingrate to demonstrate gratitude. ${ }^{29}$ If the ingrate has to be forced, then he or she is probably not really grateful.

Fourth and finally, if there is a civic obligation to work and the state legitimately enforces this duty, does government have an obligation to ensure that there is work for all who are able and willing to work? That is, is there a positive right to work such that the government should provide employment if the private sector fails to ${ }^{30}$ To require work as a condition of full civic standing when not every

\footnotetext{
27 Becker, “Obligation to Work,” pp. 43-46.

28 Jonathan Wolff, "Fairness, Respect, and the Egalitarian Ethos," Philosophy \& Public Affairs 27 (1998): 97-122; and McKinnon, "Basic Income, Self-Respect, and Reciprocity," pp. 151-152.

${ }^{29}$ For more on this point, see David Schmidtz, Elements of Justice (Cambridge: Cambridge University Press, 2006), pp. 100-101.

${ }^{30}$ A negative right to work, i.e., a right not to be prevented from accepting the job of one's choice, is generally recognized as a basic human right. For example, a regime that prohibited women from accepting work outside the home or that allowed husbands to prevent their wives from accepting employment would be in violation of this right. This right is secure only if everyone has an opportunity to freely accept a job and no unfair barriers are erected to inhibit a person's acceptance of employment. But the right does not entail that anyone, whether government or private citizen, has a duty to ensure that there are jobs for all who seek them.
} 
able-bodied citizen has the option of employment would be unfair. Those who could not find work would be stigmatized as civic inferiors, as effectively useless to the rest of his or her fellow citizens and a parasite on their contributions. A civic duty to work should therefore be paired with the state's obligation to maintain a full employment economy. ${ }^{31}$ A government could make the positive right to work effective if, for example, it enacted economic policies that spur job growth, supplied jobs in the public sector for those unable to find employment in the private sector, and offered subsidies or tax breaks to private firms that hire hard-to-employ workers. And insofar as guaranteeing a right means actively facilitating the exercise of that right, the right to work might also require government to provide the appropriate training and educational programs to meet the labor demands of a dynamic economy and to make services available to support the unemployed in their search for suitable jobs. In the United States, such a positive right to work is not generally recognized.

\section{REFUSING TO WORK: A FORM OF RESISTANCE}

Despite these reservations and unanswered questions, I think the idea of a civic obligation to work deserves to be taken seriously. From the standpoint of fairness, there is something undeniably compelling about the principle "all who eat should work," even if the precise content of this vague principle is difficult to articulate and

\footnotetext{
31 See Richard J. Arneson, "Is Work Special? Justice and the Distribution of Employment," American Political Science Review 84 (1990): 1127-1147.
} 
defend..$^{32}$ Thus, for the sake of argument, I will assume that there is a pro tanto or presumptive civic duty to work, rooted in the idea of reciprocity. My aim in what remains will be to show that the ghetto poor may nevertheless be justified in refusing to work.

Some of the legitimate reasons the ghetto poor have for refusing to work could perhaps be accommodated without altering the basic structure of U.S. society. That is, these objections could be answered by instituting relatively minor reforms, some of which have recently been initiated. To enact all the necessary reforms, however, the tax scheme would probably have to be made considerably more progressive, and perhaps almost everyone's taxes would have to increase, which many U.S. citizens would resist, some vehemently. Still, no fundamental rethinking of distributive justice would have to occur, just garnering the necessary political will—no small task, to be sure.

For example, the ghetto poor may reasonably refuse to work if the jobs available pay too little. In an affluent society, those who work full-time should not have to live in poverty, a principle widely endorsed even in the United States. One approach to this problem is to raise the minimum wage so that a full-time worker at that wage could support a family. Another, perhaps complementary, approach would be to offer income supplements (e.g., through tax credits, employer subsidies, or cost of living subsidies). ${ }^{33}$ In effect, the government could "top up" full-time workers' wages so that they are above the poverty line (here assuming, for the sake

\footnotetext{
32 Notice that the principle "all who eat should work" does not imply "those who do not work shall not eat." The former states a duty while the latter states a penalty for non-performance. As suggested earlier, one might believe there is a non-enforceable duty to work.

33 See Mary Jo Bane and David T. Ellwood, Welfare Realities: From Rhetoric to Reform (Cambridge, Mass.: Harvard University Press, 1994), pp. 143-150.
} 
of argument, that the federal poverty line is an adequate measure of impoverishment). The Earned Income Tax Credit, though not entirely adequate to the task, is a step in this direction. ${ }^{34}$

Given their difficulty securing jobs that pay a living wage, some of the ghetto poor might reject work requirements on the grounds that low-skilled workers in the new economy lack an effective right to organize and to join and maintain labor unions. Many employers of low-skilled workers have erected barriers to unionization, sought to intimidate or mislead workers who express an interest in forming unions, and exploited racial and ethnic antagonism to weaken worker solidarity. ${ }^{35}$ This means that workers have little leverage to bargain for fair compensation, benefits, and working hours. The government could respond to this concern by cracking down on union busting tactics and making it easier for workers within and across firms to form and maintain unions.

Some of the ghetto poor might refuse work because the jobs available are physically arduous, highly unpleasant or "dirty," or extremely dangerous, where these costs and risks are not adequately compensated. ${ }^{36}$ However, if these were the only jobs available, better jobs in the public sector could be created, thus putting pressure on private firms to increase compensation. And the government could

34 Given the wide geographic variance in cost of living (a fact to which the federal poverty standard does not give sufficient weight), a complementary strategy would be for public sector employers to pay their workers a decent wage by local standards and for government to require private firms that receive public funds to do the same, which will usually mean paying some low-skilled workers above the federal minimum wage. Such measures would be especially important for the ghetto poor, since they live in large metropolitan areas where the cost of living is high. And, indeed, a number of cities have passed living-wage ordinances in response to grassroots activism by and on behalf of low-income workers.

35 See Robert Michael Smith, From Blackjacks to Briefcases: A History of Commercialized Strikebreaking and Unionbusting in the United States (Athens: Ohio University Press, 2003); and Edna Bonacich, "Advanced Capitalism and Black/White Relations in the United States: A Split Labor Market Interpretation," American Sociological Review 41 (1976): 34-51.

36 For a helpful discussion of matters of fairness in regard to socially necessary "hard work," see Michael Walzer, Spheres of Justice: A Defense of Pluralism and Equality (New York: Basic Books, 1983), chap. 6. 
ensure that decent and safe working conditions prevail in all businesses, large and small, that operate in the country.

A person might also refuse to work if the jobs available required an unreasonable amount of time or exertion, leaving workers with little opportunity or energy for non-work-related activities. In an affluent society where work is required of all, it would be unfair for some to have so much more leisure than others or for some to have essentially no leisure time at all. In response to this concern, the government could demand fewer hours per day (or days per week) to remain in good civic standing. And employers could be required to give longer paid vacations to full-time workers.

One might also refuse to work if working would prevent one from caring for one's children. ${ }^{37}$ Since we have a natural duty to not only provide materially for our children but to nurture them-to ensure their proper emotional, physical, and cognitive development—parents may legitimately refuse to work if this would interfere with the fulfillment of these essential parental duties. To deal with this concern, childcare subsidies could be provided or government-financed, non-profit childcare cooperatives could be formed. Alternatively, single parents of young children could be exempted from work requirements altogether. Measures of this sort have already been implemented, though they would have to be expanded to be fully adequate.

Again, the objections to the new work regime so far mentioned could be met with relatively minor social reforms, which, while not sufficient to establish a just

\footnotetext{
37 See Elizabeth Anderson, "Welfare, Work Requirements, and Dependent-Care," Journal of Applied Philosophy 21
} (2004): 243-256. 
social structure, would constitute meaningful progress. However, some of the reasons a citizen might have for refusing to work cannot be accommodated without changing the structure of U.S. society in fundamental ways. Here I focus on three such reasons that, considering the situation of the ghetto poor, are particularly pertinent.

\section{A. The Injustice Objection}

All three reciprocity arguments are vulnerable to the objection that the basic structure of U.S. society is grossly unjust. ${ }^{38}$ When a society is manifestly unjust, refusing to work, even if there is a pro tanto civic obligation to work, may be a reasonable response. Indeed, such refusal to cooperate can be a form of political protest. Even if we were to set aside the uncompensated injustices of the past (e.g., slavery and Jim Crow segregation), which continue to affect black life chances in the present, there are current social injustices that heavily burden the ghetto poor. For instance, the structure of economic opportunity that they face is deeply unfair. Public schools are still unequal and racially segregated, and many inner-city schools are substandard. ${ }^{39}$ Consequently, the ghetto poor are severely disadvantaged when it comes to opportunities to develop marketable skills. There are great inequalities in wealth, which shape life chances in numerous ways, and which poor families in the ghetto are also on the losing end of. Even setting aside these general egalitarian

\footnotetext{
38 Some defenders of a civic obligation to work acknowledge this point and build in appropriate qualifications. See, for example, White, Civic Minimum, pp. 86-94.

39 See Gary Orfield, Susan E. Eaton, and The Harvard Project on School Desegregation, Dismantling Desegregation: The Quiet Reversal of Brown v. Board of Education (New York: The New Press, 1996); Jennifer L. Hochschild and Nathan Scovronick, The American Dream and the Public Schools (New York: Oxford University Press, 2004); and Kathryn M. Neckerman, Schools Betrayed: Roots of Failure in Inner-City Education (Chicago: University of Chicago Press, 2007).
} 
concerns, racial discrimination in employment, housing, and lending are still a problem, and there are persistent racial disparities-in income, wealth, employment, infant mortality, health outcomes, and life-expectancy - that go back to the antebellum era, never having come close to parity between blacks and whites. ${ }^{40}$ Moreover, the overall work burden is unfairly distributed in the societythat is, others are not doing their fair share of the work-and, to make matters worse, this unfair distribution is racially marked, with blacks (and Latinos) doing a disproportionate share of menial labor, hard work, and dirty jobs. ${ }^{41}$

If these justice-based criticisms of U.S. society have merit, which I think they do, this weakens if not undermines the force of the reciprocity argument for the new work regime. Taking these criticisms seriously, let's first consider the benefactor/debtor model. It is hard to see why the ghetto poor should be grateful to be citizens of the United States. In light of the burdens of injustice that they are forced to carry, resentment or indignation, not gratitude, is the apt response to their situation. To expect otherwise would be like expecting a child who has been subject to consistent parental abuse and neglect to be grateful to his or her abusive and negligent parent. One response to this objection is to point out that the ghetto poor of America could have been born into much worse circumstances-e.g., into the slums of São Paulo, Bombay, Jakarta, or Lagos. But, again, emphasizing this comparative advantage would be like attempting to exonerate abusive and negligent parents on the grounds that at least they did not let their children starve.

\footnotetext{
40 Oliver and Shapiro, Black Wealth/White Wealth; Conley, Being Black, Living in the Red; Michael K. Brown, Martin Carnoy, Elliot Currie, Troy Duster, David B. Oppenheimer, Marjorie M. Shultz, and David Wellman, Whitewashing Race: The Myth of a Color-Blind Society (Berkeley: University of California Press, 2003).

41 See Paul Gomberg, How to Make Opportunity Equal: Race and Contributive Justice (Malden: Blackwell, 2007).
} 
Even if the ghetto poor do have things to be grateful for (say, the rule of law or domestic defense) and should express this gratitude in some concrete way, it is not obvious that full-time employment is the best or only way for them to show their appreciation. They could, for instance, choose to show their gratitude and fidelity to the nation by fighting to make their society more just. And if they believe that, under current circumstances, work requirements for the poor are themselves unjust, they may carry out this fight by refusing to cooperate with the new work regime, engaging in a form of passive resistance. However, instead of objecting to a particular unjust law, as with traditional civil disobedience, they would be objecting to the social scheme as a whole.

What about the market exchange model? As is well known, attempting to derive political duties from the idea of a commercial contract has numerous difficulties. The biggest problem is that contracts must be freely entered into if they are to be binding, and most citizens of existing polities cannot be said to have made a voluntary agreement to live under the political regime into which they have been born. The vast majority of the ghetto poor, having been born in the United States and possessing meager, if any, means of support, certainly cannot be said to have chosen or consented to live under the dominion of the U.S. government. Tacit consent arguments are sometimes thought to be better than explicit consent arguments. But these arguments depend on there being a suitable alternative to living under the political regime in question, and the ghetto poor, like most citizens of the United States, cannot just leave for another country. Hypothetical consent arguments turn on it being rational to have agreed to the terms to which one finds 
oneself being held. But in a hypothetical agreement among equals, what rational person would consent to a social structure in which he or she could turn out to be a poor black denizen of a ghetto who is required to work to maintain full civic standing?

Even if we allow that a civic duty to work can be grounded in the idea of a market exchange, the injustice objection stands. The ghetto poor have not received many of the benefits they have been "promised"-e.g., equality of opportunity and the equal protection of the law. We can therefore view their refusal to work in an unjust social scheme as the moral equivalent of a rent strike against a slumlord: they refuse to pay their civic debt until the government makes good on its promise to treat all citizens fairly. There has not been a breach of civic contract but a governmental failure to perform so fundamental that the aggrieved citizens, the ghetto poor, can rightfully refuse to comply with their "agreement" to work. At a minimum, the government's failures constitute a material breach, and thus the ghetto poor have a just claim to damages.

The fair-play argument suffers from similar difficulties to the market exchange argument. Most fair-play arguments depend on the idea that the benefits of social cooperation are freely accepted, not imposed. ${ }^{42}$ But as Jeremy Moss rightly points out, since welfare recipients, who are typically poor women with young children, are among the most vulnerable in society, they cannot correctly be said to have freely accepted welfare benefits. ${ }^{43}$ What real choice do they have? But even

42 See A. John Simmons, “The Principle of Fair Play,” Philosophy \& Public Affairs 8 (1979): 307-337.

43 Jeremy Moss, “'Mutual Obligation' and 'New Deal': Illegitimate and Unjustified?" Ethical Theory and Moral Practice 9 (2006): 87-104. 
setting aside these concerns about the voluntariness of the choice, the benefits of a cooperative scheme are unfairly accepted only if the scheme itself is fair. Or, to put it differently, the moral requirement that all play by the rules is valid only if the rules are fair to everyone who plays the game. No fair-minded person would seriously suggest that, because a slave receives the benefits of shelter, food, and the rule of law, the slave thereby owes a labor debt to the slave regime that makes these benefits possible. The situation of ghetto denizens is analogous, if less dire. They undoubtedly receive some benefits as citizens of the United States (e.g., food stamps, some basic social services, and defense against external threats), but because they are so burdened by the structural injustices of the social system, they should not be considered free-riders if they refuse to comply with a civic work requirement.

\section{B. The Exploitation Objection}

A different though related reason the ghetto poor might have for refusing to work is that, under current circumstances, work requirements, or the specific terms of work, are exploitative. ${ }^{44}$ One way of developing this objection relies on the injustice objection as a premise. Though one may rightly be regarded as an exploiter (or parasite) if one does not work under just background conditions, one may be among the exploited if one is forced to work under unjust conditions. To garner benefits by extracting labor from persons who are powerless to resist because unjust

\footnotetext{
44 Piven and Cloward argue that not only is the work regime exploitative but it has the often intended effect of imposing discipline on and instilling fear in the rest of the workforce, making them more docile and easily exploitable. In response to the dehumanizing effects of the work regime, workers will often accept lower compensation, fewer benefits, and less job security to avoid sharing the degraded status of the ghetto poor. See Frances Fox Piven and Richard A. Cloward, Regulating the Poor: The Functions of Public Welfare (New York: Vintage, 1993).
} 
circumstances have been imposed on them is a paradigm case of economic exploitation. The systems of slavery, serfdom, colonial subjugation, and apartheid are examples of such an arrangement. Insofar as the ghetto poor are forced to work because of correctable, unjust background conditions, they too are rightly regarded as among the economically exploited. The legacy of slavery and Jim Crow, along with continuing employment discrimination and unequal educational opportunity, have created (or helped to create) a large class of blacks who are poor and unskilled. The result is that the black urban poor have been fashioned into a source of cheap, expendable, and exploitable labor, from which the affluent benefit.

But the exploitation objection would still have force even if the basic structure of U.S. society had not exceeded the threshold for tolerable injustice. Many Americans maintain that the ghetto poor remain poor because of bad option luck for which they are responsible. Had they worked harder, avoided risky behavior, delayed childbearing until marriage, developed useful skills, and so on, they would not be in such a dire situation. Because of this irresponsible conduct, their vulnerable economic position is deserved-or at least they should bear the economic costs of their unwise behavior-and it is therefore not exploitative for their fellow citizens to require them to work as a condition of material support. However, even if we allow that such charges are rightly applied to adults whose bad choices have left them confined to the ghetto, what of those persons who grow up under ghetto conditions? ${ }^{45}$ Their disadvantage is the result of bad brute luck, not bad option luck. In view of their undeserved economic disadvantage and insecurity,

${ }^{45}$ A shockingly high percentage of the black poor were born into ghetto conditions. See Patrick Sharkey, "The Intergenerational Transmission of Context," American Journal of Sociology 113 (2008): 931-969. 
even if economic reciprocity is, in general, a requirement of justice and the basic

structure of U.S. society is reasonably just, forcing the indigenous black urban poor

to work is exploitative. ${ }^{46}$ It is a case of profiting from the labor of people who are

compelled to work because of weaknesses and vulnerabilities that are not of their

making. ${ }^{47}$

In fact, the situation is worse than this. Under the new work regime, the

indigenous ghetto poor are in a self-reproducing exploitative relationship with

affluent citizens. The structure of a self-reproducing exploitative relationship is as

follows:

$X$ and $Y$ are in a self-reproducing exploitative social relationship if: (i) $Y$ is regularly forced to make sacrifices that result in benefits for $X$; (ii) $X$ obtains these benefits by means of a power advantage that $X$ has over $Y$; and (iii) as a result of conditions (i) and (ii) $X^{\prime}$ s power advantage over $Y$ is maintained (or is increased) and $Y$ remains in the condition of being forced to make sacrifices for $X^{\prime}$ s benefit. 48

\footnotetext{
46 Some might object that since the ghetto poor will also benefit from the new work regime, the social arrangement cannot be exploitative. For instance, some theorists attempt to explain what it means for an exploiter to benefit at the expense of the exploited in distributive terms. They claim, for example, that a relationship is exploitative only if the benefits of the relationship are such that the exploiter has (much) more to gain from the relationship than the exploitee, or such that the exploitee stands only to lose from it. However, the severely disadvantaged are often made better off, materially speaking, by an exploitative arrangement. An exploitative relationship need not be zero-sum in character and may even be a pareto-optimal improvement for the two parties. The fact is, exploitees often have a lot to gain from their relationship with their exploiters, sometimes even more than the exploiters themselves. Indeed, the benefits of being exploited often explain (at least partially) why the exploitee enters into the relationship. For a development of this point, see Allen W. Wood, "Exploitation," Social Philosophy and Policy 12 (1995): 147-148; and Alan Wertheimer, Exploitation (Princeton: Princeton University Press, 1996), pp. 14-19. For a general critique of the distributive approach to exploitation, see Julius Sensat, “Exploitation," Noûs 17 (1984).

47 If all of the profits from the new work regime were funneled into programs and initiatives to abolish ghetto conditions, such that the ghetto poor would ultimately reap all the benefits of the arrangement, then the exploitation object could perhaps be met. To set up this arrangement, the ghetto poor would probably have to be offered public sector jobs or employment with non-profit organizations to ensure that capitalist firms and affluent private citizens were not able to take advantage of the cheap supply of labor.

48 This account is developed and defended in my, "Parasites, Pimps, and Capitalists: A Naturalistic Conception of Exploitation," Social Theory and Practice 28 (2002): 381-418.
} 
Thus, in a self-reproducing exploitative social relationship, a social relation that has the basic structure outlined in conditions (i) and (ii) has as one of its causal consequences that the conditions for the continuation of a relationship that preserves that structure are thereby reproduced. What this account does, then, is help us to see why some exploitative relationships tend to persist: the very structure of these relationships tends to secure their continuance.

Because of the new work regime, this self-reproducing exploitative relationship exists between the indigenous ghetto poor and their more affluent fellow citizens. The basic problem is this: many of the ghetto poor who have submitted to the requirements of the new work regime nevertheless remain poor. ${ }^{49}$ They simply become part of the working poor, often serving the private needs of the well off-e.g., performing the roles of maids, nannies, dishwashers, maintenance workers, and so on. Others fall back into poverty because of recessions, periods of economic restructuring, or mass layoffs. The schools available to the ghetto poor are often so substandard that they do not enable upward mobility. Thus, when work requirements do not allow for skills enhancement or promotion to better-paid positions, these requirements are fairly interpreted as attempts to profit from extracting burdensome and unrewarding labor from the weak and vulnerable. Work enforcement, under these circumstances, is disempowering-it ensures that the ghetto poor are a permanently exploitable class.

\footnotetext{
49 Sandra Danziger, Mary Corcoran, Sheldon Danziger, and Colleen M. Hekin, "Work, Income, and Material Hardship after Welfare Reform," Journal of Consumer Affairs 34 (2000): 6-30.
} 


\section{The Expressive Harm Objection}

In addition to the injustice and exploitation objections, the ghetto poor may refuse to cooperate with the new work regime because they believe that work mandates demean and stigmatize them. There are three versions of this objection that I want to briefly outline.

The social identity of most black Americans is defined, in part, by being the descendants of slaves. ${ }^{50}$ As Tocqueville argued, once the status of "slave" was something only a member of the black race could have, the stigma of forced servitude became attached to "blackness" itself. This stigma is so powerful that it stains blacks that were never slaves and has persisted for generations after slavery ended. To be black has come to mean, in the minds of many, being a member of a people who, because of cowardice and servility, and to its everlasting shame, submitted to slavery. And this stigma is one of the reasons African Americans have insisted that black slaves actively resisted slavery, from armed rebellion to shirking work. The ghetto poor may thus justifiably fear that to accommodate themselves to the new regime of work, with its state sanctioned work mandates, would reinforce or resurrect this stigma.

It may be objected that this account, however applicable in the past, no longer applies to the black condition. Many would argue that the stigma of slavery has faded and will never return..$^{51}$ Nevertheless, this historical stigma tells us

\footnotetext{
50 For an account of what it means to be "black" in America, see my We Who Are Dark: The Philosophical Foundations of Black Solidarity (Cambridge, Mass.: Harvard University Press, 2005), chap. 6. Also see my article (with Lionel K. McPherson) "Blackness and Blood: Interpreting African American Identity," Philosophy \& Public Affairs 32 (2004): 171-192.

51 For a recent defense of the claim that the stigma of blackness remains intact, see Glenn C. Loury, The Anatomy of Racial Inequality (Cambridge, Mass.: Harvard University Press, 2002).
} 
something important about what forced work means to a people descended from black slaves. As members of an historically oppressed yet proud social group, most blacks feel a duty to remember the horrendous moral crimes perpetrated against their ancestors. Some demand reparations even now. Almost all embrace the legacy to resist race-based oppression, particularly those forms that are similar or related to past racial injustices. Blacks are therefore suspicious of and often bristle at any social arrangement that has the look or feel of race-based servitude. And, quite apart from the conscious intent of those who support the new work regime, the symbolic meaning of such a regime when targeted at the most vulnerable and powerless segment of the black population is, I think, a sufficient reason to be defiant in the face of its demands.

The second version of the expressive harm objection focuses, not just on race and class, but on space. Recall that ghettos are defined as poor black metropolitan neighborhoods. "The 'hood," as ghettos are sometimes called, is a place most people do not want to pass through, let alone reside in. ${ }^{52}$ It is that dangerous place where the "underclass" dwells, a place that elicits fear, contempt, and pity. It is a segregated space, a place of dishonor set apart to contain the undeserving dark masses. ${ }^{53}$ The stigma attached to the ghetto is not just a racial stigma or a poverty stigma but a stigma that marks residential neighborhoods. Thus, unless the new work regime enables people to exit the ghetto or transforms poor segregated

\footnotetext{
52 See, for example, Douglas S. Massey and Nancy A. Denton, American Apartheid: Segregation and the Making of the Underclass (Cambridge, Mass.: Harvard University Press, 1993); Mary Pattillo-McCoy, Black Picket Fences: Privilege and Peril Among the Black Middle Class (Chicago: University of Chicago Press, 1999); and William Julius Wilson and Richard P. Taub, There Goes the Neighborhood (New York: Knopf, 2006).

53 Or maybe it is a "neighborhood in transition" if it is undergoing the process of gentrification and the poor are being priced out. But I will set this case aside.
} 
neighborhoods into mixed-income and integrated ones, ghetto denizens may reasonably refuse to comply. For in the absence of realistic exits or concerted efforts to abolish ghetto conditions, forcing the ghetto poor to work would be the functional equivalent of state-sponsored labor camps or workhouses for the black poor, as the workers would still be effectively confined to the dark ghetto. The black urban poor may legitimately refuse to accept jobs under these circumstances on the grounds that to willingly comply would be humiliating.

Third and finally, many Americans have racial animus toward or unconscious biases against black Americans. In particular, there is considerable evidence that some Americans oppose welfare entitlement programs because they are hostile to or prejudiced against blacks. ${ }^{54} \mathrm{~A}$ longstanding and deeply offensive stereotype about blacks is that they are congenitally lazy. ${ }^{55}$ The ghetto poor would have grounds to refuse work if they have a justified belief that their fellow citizens have erected a work regime out of racist motives. A work regime, despite its ostensible race-neutrality, would then be justly considered a veiled expression of contempt for black citizens and a sign of the society's lack of equal respect for blacks.

All three of these expressive harm objections are that much more forceful if the injustice and exploitation objections are sound. Submitting to an unjust and exploitative regime is anathema to anyone with a healthy sense of self-respect. But for blacks to accommodate themselves to an unjust and exploitative regime that stigmatizes and conveys contempt for poor black people is, for some at least, a fate

\footnotetext{
54 See, for example, Jill Quadagno, The Color of Welfare: How Racism Undermined the War on Poverty (New York: Oxford University Press, 1994); Herbert J. Gans, The War Against the Poor: The Underclass and Antipoverty Policy (New York: Basic, 1995); and Martin Gilens, Why Americans Hate Welfare: Race, Media, and the Politics of Antipoverty Policy (Chicago: University of Chicago Press, 1999).

55 There is an old racist joke that goes: "How do you starve a nigger? Put his food stamps under his work boots."
} 
worse than poverty. The ghetto poor, apprehending the symbolic meaning of a work regime, may therefore reject it as insulting and choose non-work to preserve their dignity. ${ }^{56}$

\section{CONCLUSION}

I have shown that even if joblessness is a crucial causal factor in the explanation for ghetto poverty, it does not follow that the new work regime is the most appropriate, or even a morally permissible, solution. There are important questions about what activities should count as work and about how much work should be expected, and some plausible answers to these questions suggest that a less austere work scheme than generally favored would be morally preferable. There are also compelling reasons to doubt that the new work regime, in its current form, could be justified to the ghetto poor. At a minimum, there are policies (e.g., income subsidies, labor laws, and childcare subsidies and exemptions) that would have to be instituted or expanded before work mandates could be legitimately enforced. More radically, I have argued that, in the absence of fundamental changes in the basic structure of U.S. society, work mandates are unjust, exploitative, insulting, and stigmatizing. Moreover, there are alternative social arrangements-such as an all-volunteer workforce and basic income support-worth serious consideration. Throughout, I have emphasized how considerations of social justice should inform government's

\footnotetext{
56 Though I will not develop it further here, there is a fourth reason some among the ghetto poor may refuse to work. They may reasonably complain that they have been denied a fair opportunity to secure meaningful work-e.g., work that they find intrinsically satisfying or interesting, that exercises and allows them to develop their most basic human capacities, or that suits them given their abilities and fundamental aims. See, for example, Adina Schwartz, "Meaningful Work," Ethics 92 (1982): 634-646; Russell Muirhead, Just Work (Cambridge, Mass.: Harvard University Press, 2004); and Jeffrey Moriarty, "Rawls, Self-Respect, and the Opportunity for Meaningful Work," Social Theory and Practice 35 (2009): 441-459.
} 
and citizens' responses to joblessness in the ghetto. And I have urged that those of us who sincerely want to improve the life prospects of the ghetto poor should give greater weight to the moral reasons that they may have for choosing not to work. ${ }^{57}$

57 Versions of this Article were presented at Harvard University, Stanford University, the American Philosophical Association (Eastern Division), the University of Virginia, the American Political Science Association, and the "Rights and Reciprocity" conference sponsored by the Academic Center of Law and Business in Tel Aviv. I thank the participants at these events for their comments and criticisms. For helpful feedback, I also thank Eric Beerbohm, Harry Brighouse, Moshe Cohen-Eliya, Nir Eyal, Evan Farr, Lani Guinier, Walter Johnson, Lawrence Lessig, Jonathan Marks, Allegra McLeod, Kristina Meshelski, Tim Scanlon, Shlomi Segall, Steven Shiffrin, Andrew Valls, Daniel Viehoff, and an anonymous reviewer for this journal. Research for this Article was generously supported by the Edmond J. Safra Center for Ethics at Harvard University. 